\title{
Different Criteria of Feed Formulation for Broilers Aged 43 to 49 Days ${ }^{1}$
}

Author(s)

Araújo LF ${ }^{*}$

Junqueira $\mathrm{OM}^{3}$

Araújo $\mathrm{CSS}^{3}$

Faria $\mathrm{DE}^{2}$

Andreotti $\mathrm{MO}^{4}$

Part of Doctoral thesis of first author.

2 Universidade de São Paulo - Faculdade de Zootecnia e Engenharia de Alimentos - USP/FZEA, Pirassununga - SP.

3 Universidade Estadual Paulista - Faculdade de Ciências Agrárias e Veterinárias de Jaboticabal - UNESP/FCAV, Jaboticabal - SP.

4 Universidade Federal do Mato Grosso do Sul - UFMS, Campo Grande - MS.

\section{ABSTRACT}

An experiment was carried out to evaluate different formulated feeds for broilers from 43 to 49 days of age. Six hundred male Cobb broilers were distributed in a completely at random experimental design with 3 treatments ( 3 different criteria of feed formulation) and 4 repetitions per treatment, with 50 birds each. Diets were formulated with different criteria of digestible amino acid inclusion (methionine, methionine+cystine, lysine and threonine), according to the profiles recommended by Baker and Chung (1992), Degussa (1997) and Rostagno (2000) Live performance and carcass yield were evaluated in birds fed the different diets from 43 to 49 days of age). The profile established by Degussa (1997) resulted in best live performance. All profiles supplied the nutritional requirements of the birds for adequate carcass yield, but Degussa (1997) profile resulted in highest breast yield.

\section{INTRODUCTION}

One of the most important roles of animal production is to provide high quality protein for human consumption, and to achieve this proposal animals should be fed correct proportions of high quality protein in the diets.

Amino acids are key factors in animal nutrition since protocols used to evaluate protein quality are related to amino acid supply. Poultry feed formulation was until recently based on the concept of crude protein, which frequently resulted in diets containing amino acid levels higher than the actual requirements of birds. Amino acid excess is poorly used by birds, as it must be reduced to nitrogen and then excreted as uric acid. Excessive protein levels in food not only result in higher formulation costs, but also affect bird performance. The commercial availability of synthetic amino acids has allowed nutritionists to formulate cheaper feeds that contain adequate levels of amino acids. However, protein levels are still too high. Birds do not have a high crude protein requirements, but there should be sufficient protein to provide an adequate nitrogen supply for synthesis of non-essential amino acids. The formulation of diets with lower crude protein levels will become feasible as other synthetic amino acids become economically available.

Poultry amino acid requirements are not easily assessed, as they are influenced by several factors. Nutritionists must take into account such factors when formulating several diets to satisfy the requirements of different bird categories, as well as different nutritional standards.

The concept of ideal protein has been developed recently and is defined as the balance of digestible amino acids needed to supply the absolute requirements of all amino acids needed for maintenance and production, with no excesses or deficiencies. A reference amino acid is chosen and the requirement of other amino acids are estimated as proportions of this one. 
Lysine is used as the reference amino acid despite being the second mostly limiting amino acid in broiler feeding after methionine. The reason is that lysine is easier to analyze than methionine and cystine, and it is used exclusively in muscle protein synthesis and not involved in other metabolic routes, such as maintenance and feathering. Moreover, there is more information available on lysine requirement as compared to other amino acids (Baker \& Chung, 1992). According to Pack (1995), diet formulation based on total amino acid basis is similar to diet formulation based on crude energy.

Crude protein with excessive amino acid levels (levels $50 \%$ higher than normal requirements) can still be used in poultry commercial diets with no effect on performance parameters. On the other hand, when diets are formulated with synthetic amino acids, which presumably are available for absorption, minor changes in levels may influence feed efficiency, and especially feed intake.

The most important parameters to typify carcass quality are carcass yield, breast meat yield, and fat content in the carcass. Breast meat yield is the carcass component with the highest economic value, if the bird is considered as a whole. During the production cycle, breast meat continuously increases as a percentage of body weight (Acar et al., 1993; Fischer 1994). When any limitation in the amino acid supply in the diet is found, breast meat accretion will be the first site of protein synthesis to be affected.

Interactions among amino acids in the diet must also be considered. A response to lysine deficiency is observed only if methionine is properly supplied, which shows the importance of a well-balanced amino acid profile. Weight gain and breast meat yield in broilers slaughtered at 54 days of age were affected by an interaction between dietary lysine and threonine. High dietary levels of lysine limited performance if threonine levels were not considered (Kidd et al., 1997).

Few studies evaluated different formulation criteria based on digestible amino acids for broilers. It is important to emphasize that optimal amino acid profiles are very different when considering different objectives (Pack, 1995). Body proteins contain high lysine levels approximately two times higher than levels of sulfur amino acids and threonine. However, feather proteins contain very low lysine, whereas sulfur amino acid levels are very high due to the presence of cystine. Likewise, methionine+cystine (met+cyst) and threonine maintenance requirements are much higher than lysine requirements. In order to determine the proportions of essential amino acids to lysine, the described profiles must be combined with protein accretion data in broilers.

This study evaluated live performance and carcass yield of broilers fed diets based on digestible amino acids and formulated with different criteria during the period of 43 to 49 days of age.

\section{MATERIAL AND METHODS}

The study was carried out in the poultry facilities of FCAV/UNESP of Jaboticabal, Brazil, in order to evaluate the use of different criteria in feed formulation for broilers aged 43 to 49 days.

The poultry house was open-sided, measuring $30 \mathrm{x}$ $6.65 \mathrm{~m}$ and $2.5-\mathrm{m}$ high, with north-south roof orientation, asbestos roof tiles and no ridge opening. There was a tile wall with $0.40 \mathrm{~m}$ high and wire mesh on side walls protected by adjustable yellow plastic curtains, which were used in internal temperature control.

The boxes measured $3.15 \times 1.50 \mathrm{~m}$ each, and the floor was covered with wood shavings as litter material. Infrared lamps were used for chick brooding and chick feeders and pressure bell drinkers were used during the starter phase. Initial equipment was gradually replaced, by introducing equipment for adult birds on the $3^{\text {rd }}$ day. Replacement by adult equipment was completed when the birds were 5 days of age. Brooding temperature control as well as curtain management was according to bird behavior. Light schedule was 24 hours of light throughout the experimental period. Birds were vaccinated against Newcastle disease and Infectious Bursal Disease via drinking water at 10 days of age. Feed and water were offered ad libitum.

During the initial (1-21 days) and growing (22-42 days) phases, broilers were raised as described by Gomes et al. (1996). Birds were then selected, weighed and distributed randomly in the experimental treatments. Experimental period lasted from 43 to 49 days of life.

At 43 days of age, six hundred male Cobb broilers were distributed in a completely randomized experimental design with 3 treatments ( 3 criteria of feed formulation) and 4 replicates per treatment, with 50 birds each. It was evaluated live performance (weight gain, feed intake and feed conversion) and carcass yield in the broilers that had been fed diets obtained according to different formulation criteria, involving digestible methionine, methionine+ cystine, lysine and threonine, and based on the recommendations of Baker \& Chung (1992), Degussa (1997), and Rostagno (2000). Amino acid profiles of each formulation criteria are shown in Table 1. 
Table 1 - Digestible amino acids expressed as lysine percentage in diets fed from 43 to 49 days of age, based on different feed formulation criteria.

\begin{tabular}{lccc} 
& \multicolumn{3}{c}{ CRITERIA } \\
\cline { 2 - 4 } Amino acid & Baker and Chung & Degussa & Rostagno \\
Lysine & $100(0.97)$ & $100(0.97)$ & $100(0.97)$ \\
Methionine & $37(0.36)$ & $47(0.46)$ & $39(0.38)$ \\
Met+Cys & $75(0.73)$ & $84(0.81)$ & $71(0.69)$ \\
Threonine & $70(0.68)$ & $64(0.62)$ & $57(0.55)$ \\
\hline
\end{tabular}

At the end of the experimental period, four birds of each replicate were slaughtered following a 6-hour fasting in order to determine carcass yield. Carcass yield was determined as the weight of the eviscerated carcass in relation to live weight after fasting. Breast, legs (legs and thighs), wings, back, head and neck, feet, and abdominal fat weights were determined and expressed as percentages of eviscerated carcass weight.

Abdominal fat was defined as the adipose tissue present around the vent, the bursa, and the adjacent abdominal muscles, as described by Smith (1993).

Experimental feeds were based on corn, soybean meal, corn gluten, soybean oil, dicalcium phosphate, calcitic limestone, salt, synthetic amino acids, and vitamin and mineral supplements. Lysine level in the experimental basal diet was as recommended by Rostagno et al. (2000). Experimental diets were isoproteic and isocaloric. Different amino acid levels were used according to each evaluated profile, but equal digestible lysine levels were used (Table 2).

Data were analyzed using SAS software - Statistic Analysis System (SAS, 1986) and means were compared by Tukey's test at $5 \%$.

\section{RESULTS AND DISCUSSION}

Live performance of broilers fed different digestible amino acid profiles is presented in Table 3. Birds fed with the profile established by Rostagno et al. (2000) had lower weight gain and poorer feed conversion. Degussa (1997) amino acids profiles showed better weight gain and feed conversion $(p<0.05)$ when compared to other profiles. We can speculate that this formulation criteria gives higher digestible methionine and methionine+cystine levels in the diet improving bird performance. Feed intake was different among treatments during the experimental period. Birds fed with the profile recommended by Rostagno et al. (2000) had higher feed intake, whereas the lowest feed intake was seen in birds fed with the profile of Degussa (1997).

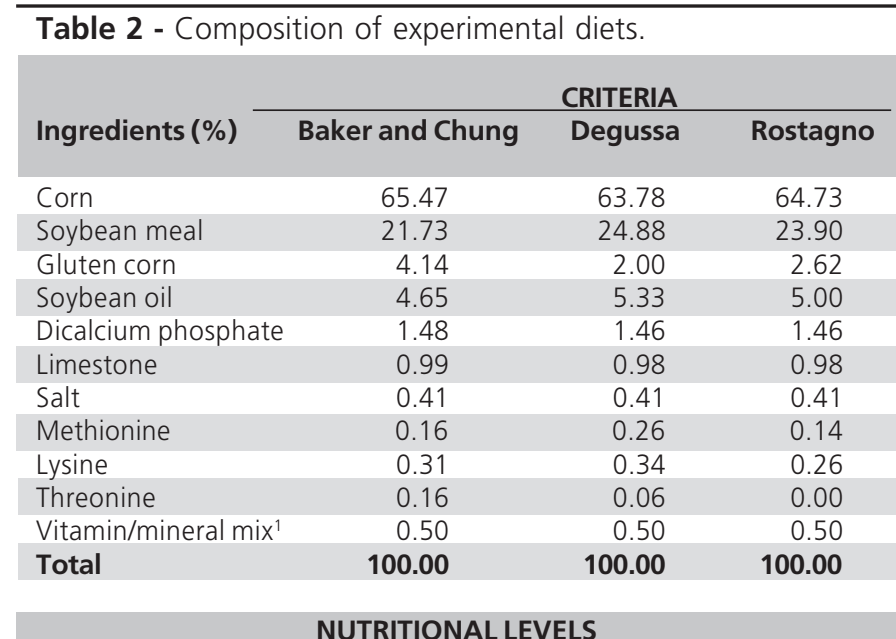

\begin{tabular}{|c|c|c|c|}
\hline ME (kcal/kg) & 3,300 & 3,300 & 3,300 \\
\hline CP (\%) 18.00 & 18.00 & 18.00 & \\
\hline Calcium (\%) & 0.83 & 0.83 & 0.83 \\
\hline P, available (\%) & 0.38 & 0.38 & 0.38 \\
\hline Sodium (\%) & 0.20 & 0.20 & 0.20 \\
\hline Lysine, digestible (\%) & 0.97 & 0.97 & 0.97 \\
\hline Methionine, dig (\%) & 0.36 & 0.46 & 0.38 \\
\hline Methionine+cystine, dig(\%) & 0.73 & 0.81 & 0.69 \\
\hline Threonine, dig (\%) & 0.68 & 0.62 & 0.55 \\
\hline \multicolumn{4}{|c|}{$\begin{array}{l}1 \text { - Levels per kg of diet: } 300,000 \mathrm{lU} \text { vit } \mathrm{A} ; 5,000 \mathrm{IU} \text { vit. } \mathrm{D}_{3} ; 200 \mathrm{mg} \text { vit. E; } \\
98 \mathrm{mg} \text { vit. } K ; 400 \mathrm{mg} \text { vit } \mathrm{B}_{1} ; 350 \mathrm{mg} \text { vit } \mathrm{B}_{2} ; 1,000 \mathrm{mcg} \text { vit } \mathrm{B}_{12} ; 20,000 \mathrm{mg} \\
\text { niacin; } 2,000 \mathrm{mg} \text { Pantothenic acid; } 3,000 \mathrm{mg} \text { Growth promoter; } 50 \mathrm{mg} \\
\text { Se; } 125 \mathrm{~g} \text { antioxidant, } 24,000 \mathrm{mg} \mathrm{Mn;} 20,000 \mathrm{mg} \mathrm{Zn} ; 10,000 \mathrm{mg} \mathrm{Fe} ; \\
15,000 \mathrm{mg} \mathrm{Cu} ; 250 \mathrm{mg} \mathrm{I.}\end{array}$} \\
\hline
\end{tabular}

Table 3 - Performance of broiler chickens fed diets formulated with different digestible amino acid criteria from 43 to 49 days of age.

\begin{tabular}{|c|c|c|c|c|}
\hline \multirow[b]{2}{*}{ Parameter } & \multicolumn{3}{|c|}{ CRITERIA } & \multirow{2}{*}{$\frac{\mathrm{CV}}{\mathrm{( \% )}}$} \\
\hline & Baker and Chung & Degusssa & Rostagno & \\
\hline Weight gain, g & $560 a b^{1}$ & $577 a$ & $554 b$ & 6.80 \\
\hline Feed intake, $g$ & $1,118 a b$ & $1,096 b$ & $1,181 \mathrm{a}$ & 4.81 \\
\hline Feed conversion, g & $\mathrm{g} / \mathrm{g} \quad 2.00 \mathrm{ab}$ & $1.90 \mathrm{~b}$ & $2.13 a$ & 6.24 \\
\hline
\end{tabular}

Growing broiler diets obtained according to different formulation criteria did not result in different performance (Araujo, 2001). On the other hand, Araujo et al. (2002) reported that starting broiler diets formulated according to different formulation criteria resulted in better weight gain and feed conversion for the profile established by Baker and Chung (1992) when compared to other evaluated profiles.

Carcass evaluation of broilers fed diets produced according to different formulation criteria and based on digestible amino acids are shown in Table 4. Birds fed diets according to Degussa (1997) profile had higher breast yield as compared to the other treatments 
$(p<0.05)$, and back yield was higher $(p<0.05)$ in birds fed with the profile established by Rostagno et al. (2000). Such treatment also resulted in higher wing yield and lower proportion of abdominal fat. Highest yields of carcass, legs, head+neck, and feet were obtained in birds fed according to the profile recommended by Baker \& Chung (1992).

\begin{tabular}{|c|c|c|c|c|}
\hline & & CRITERIA & & CV \\
\hline Parameter & Baker and Chung & Degusssa & Rostagno & (\%) \\
\hline Carcass & $81.09 a^{1}$ & $80.69 a$ & $80.65 a$ & 4.28 \\
\hline Breast & $27.19 a b$ & $28.45 \mathrm{a}$ & $27.04 b$ & 4.64 \\
\hline Legs & $28.85 a$ & $28.54 \mathrm{a}$ & $28.74 \mathrm{a}$ & 3.29 \\
\hline Wings & $10.12 \mathrm{a}$ & $10.17 a$ & $10.19 a$ & 4.48 \\
\hline Back & $17.9 \mathrm{ab}$ & $17.05 b$ & $18.74 \mathrm{a}$ & 7.82 \\
\hline Head + neck & $7.55 a$ & $7.48 a$ & $7.11 \mathrm{a}$ & 6.68 \\
\hline Feet & $5.40 \mathrm{a}$ & $5.34 a$ & $5.31 \mathrm{a}$ & 9.22 \\
\hline Abdominal Fat & $2.96 \mathrm{a}$ & $2.97 a$ & $2.87 \mathrm{a}$ & 14.71 \\
\hline
\end{tabular}

Pack (1995) have established an ideal amino acid composition in the diet based on experimental findings and the net requirements for specific metabolic functions. The suggested ratios of methionine, met+cys and threonine in relation to digestible lysine for broilers during the finisher phase should be 45:82:70, respectively.

It is worth noting that an adequate level of digestible lysine should be determined, since all amino acids are established according to the lysine level in the ideal balance of amino acids. Because lysine level must be adapted to dietary metabolizable energy level, crude protein level, bird sex, breed and age, it is relatively difficult to establish a general set of recommendations. The difficulty increases even further if different economic scenarios are considered.

Optimal levels of amino acids are different in each specific situation. For companies that produce birds for further processing, it is more cost-effective to formulate diets with higher amino acid levels as compared to companies that sell whole carcasses. Such difference occurs due to the increase in the income that results from the higher breast meat yield produced by diets with high amino acid levels. Due to the high economical value of breast meat and the relative low cost of synthetic methionine, lysine and threonine, it is interesting for broiler integration to supply higher amino acid levels in the diet as compared to feed manufacturers, that produce and sell complete feed formulations.

\section{CONCLUSIONS}

The results obtained in this study allow to conclude that all evaluated profiles are in accordance with bird nutritional requirements if the production is aimed to the whole carcass market. However, the profile established by Degussa (1997) results in the best breast yield, which would be more appropriate if the objective is to sell commercial cuts.

\section{REFERENCES}

Acar N, Moran ET, Mulvaney DR. Breast muscle development of commercial broilers from hatching to twelve weeks of age. Poultry Science 1993; 73(4):317-25.

Araujo LF. Estudo de diferentes critérios de formulação de rações, com base em aminoácidos totais e digestíveis, para frangos de corte. [Tese Doutorado]. Jaboticabal (SP):Universidade Estadual Paulista; 2001

Araujo LF, Junqueira OM, Araujo CSS, Artoni SMB, Faria Filho DE. Diferentes critérios de formulação de rações para frangos de corte no período de 1 a 21 dias de idade. Revista Brasileira de Ciência Avícola 2002; 4(3):195-202.

Baker DH, Chung TK. Ideal protein for swine and poultry. Biokyowa Publishing Co., St. Louis, p. 1-17, 1992.

Degussa. Amino acid recommendations for poultry. Feed Formulation Guide. Hanau: Degussa AG, 1997.

Fischer $C$. Use of amino acids to improve carcass quality of broilers. Feed Mix 1994; 2(4):17-20.

Gomes PC, Albino LFT, Silva MA. Criação de frangos de corte. Informe Técnico. Viçosa; 1996. 18 p.

Kidd MT, Kerr BJ, Anthony NB. Dietary interactions between lysine and threonine in broilers. Poultry Science 1997; 76(4):608-614.

Pack M. Proteína ideal para frangos de corte. Conceitos e posição atual. In: Conferência Apinco de Ciência e Tecnologia Avícolas; 1995; Curitiba, Paraná. Brasil. p.95-110.

Rostagno HS, Albino LFT, Donzele JL, Gomes PC, Ferreira AS, Oliveira RF, Lopes DC. Composição de alimentos e exigências nutricionais de aves e suínos: Tabelas Brasileiras, Viçosa, MG, UFV, 141p., 2000.

SAS Institute Inc. (1986) SAS User's Guide: Statistics. SAS Institute Inc., Cary, NC

Smith MO. Parts yield of broilers reared under cycling high temperatures. Poultry Science 1993; 72(10):1207-14. 